Article

\title{
Old and Cosmopolite: Molecular Phylogeny of Tropical-Subtropical Kites (Aves: Elaninae) with Taxonomic Implications
}

\author{
Ivan J. Starikov*(D) and Michael Wink*(D) \\ Department of Biology, Institute of Pharmacy and Molecular Biotechnology, Heidelberg University, \\ Im Neuenheimer Feld 364, 69120 Heidelberg, Germany \\ * Correspondence: i.starikov@stud.uni-heidelberg.de (I.J.S.); wink@uni-heidelberg.de (M.W.) \\ LSID: urn:lsid:zoobank.org:act:D25DE61A-7AE6-46BC-919A-44071B7AB9EA \\ (http://zoobank.org/NomenclaturalActs/D25DE61A-7AE6-46BC-919A-44071B7AB9EA) \\ check for \\ updates
}

Received: 28 June 2020; Accepted: 26 August 2020; Published: 28 August 2020

\begin{abstract}
Kites of the Elaninae group are small and medium-sized, mostly tropical raptors traditionally considered as an early diverged subfamily of the Accipitridae. We used nucleotide sequences of three genetic markers (mitochondrial $C y t b$ and COI, nuclear RAG-1) to reconstruct the phylogenetic relationships of the Elaninae, other kites, and representatives of different families of diurnal raptors. Our results confirm the basal position of Elaninae, separated the latest in Early Miocene, including Chelictinia riocourii, which was not sequenced before and belongs to this group. Not only DNA data but also cytological, morphological, and ecological data show the singularity of Elaninae. We suggest elevating this group to family level as Elanidae within the order Accipitriformes. It includes Gampsonyx swainsonii as a monotypic subfamily because of distinctive traits and DNA sequence data. Taxonomic implications for other macrogroups of Accipitriformes are discussed.
\end{abstract}

Keywords: kites; phylogeny; Elaninae; tropics; taxonomy; mtDNA; RAG-1

\section{Introduction}

Elaninae Blyth, 1850, are traditionally considered as one of raptor subfamilies of the family Accipitridae Viellot, 1816 [1-3]. They are small and medium-sized red-eyed kites and inhabit mostly semi-open and open tropical biomes in all continents [4,5] (Figure 1). Actually, this small group counts three genera, and two of them Gampsonyx (Vigors, 1825) and Chelictinia (Lesson, 1843) are monotypic. The small-tailed colorful Pearl Kite Gampsonyx swainsonii (Vigors, 1825), living in Central and South America, consists of three subspecies. The Scissor-tailed Kite Chelictinia riocourii (Temminck, 1821) is a monotypic species, small gray-white kite with a long forked tail from Central Africa. The genus Elanus (Savigny, 1809), includes tropical and subtropical white-gray-black kites of medium size with short tails quite similar to each other. This taxon consists of four species: Old World cosmopolite Black-winged Kite E. caeruleus (Desfontaines, 1789) with three [6,7] or four [8,9] subspecies recognized; American White-tailed Kite E. leucurus (Vieillot, 1818) with two subspecies; and Australian monotypic kites: Black-shouldered E. axillaris (Latham, 1801) and Letter-winged E. scriptus (Gould, 1842). 


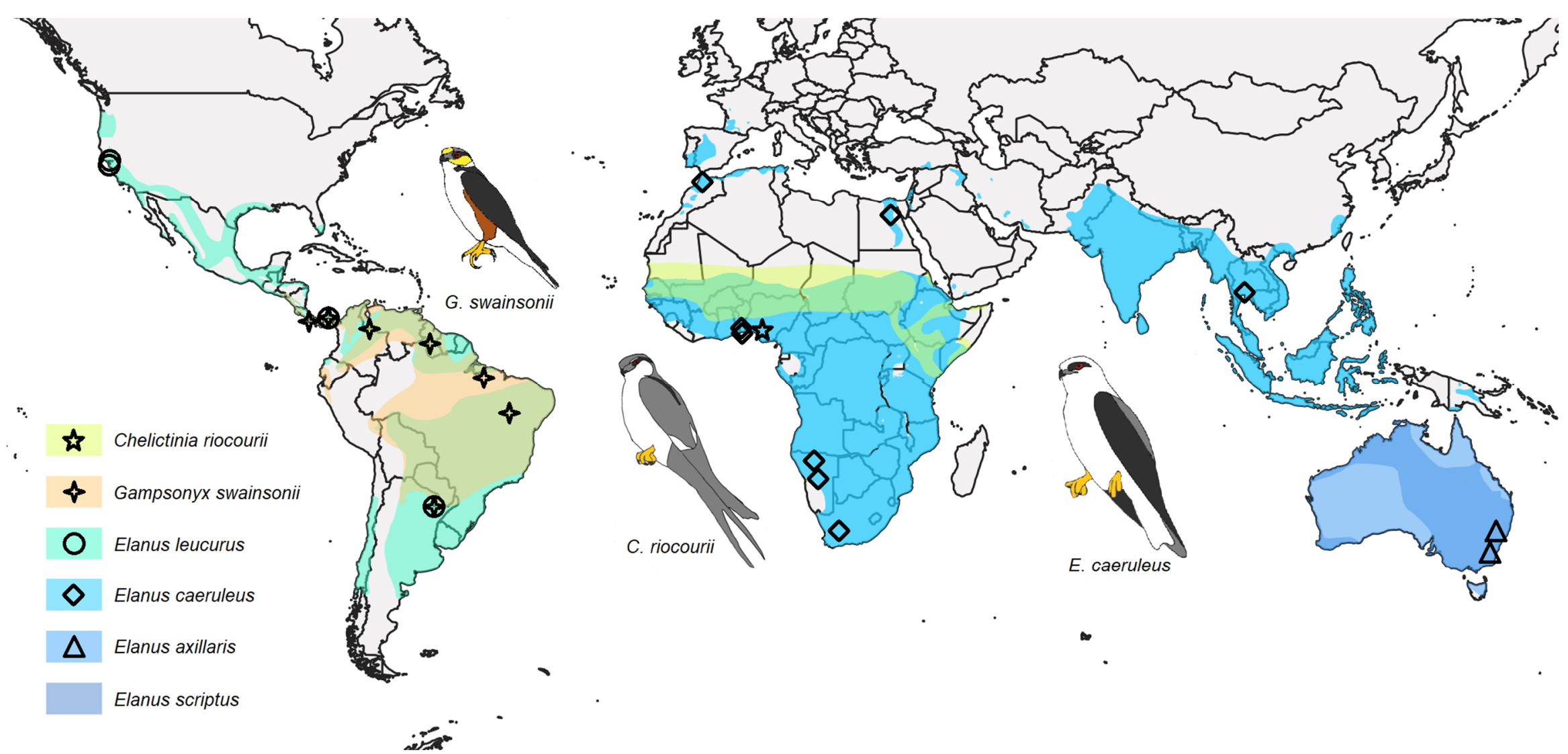

Figure 1. Sample locations (geometric symbols), range (from [10-15]), and schematic illustrations of Elanin kites genera representatives. 
When the Elaninae subfamily was described to distinguish from other diurnal birds of prey, Blyth [1] included inside Elanus, Chelictinia, and Gampsonyx genera, but he considered the last as part of Elanus. However, Ridgway [16] used for these raptors the name "group Elani" inside of the subfamily Buteoninae (Vigors, 1825), with genera Elanus, Gampsonyx, and further [17] Elanoides (Vieillot, 1818). After an osteological examination, Shufeldt [18] moved Elaninae inside in the family Milvidae (Vigors, 1825). The last suggestion was not supported by later taxonomists. Pycraft [19] placed Elaninae in Buteonidae (synonym of Accipitridae) and added Macheiramphus (Bonaparte, 1850). Later, its position was questioned and this genus is conditionally placed among Perninae (Blyth, 1850) [3]. Peters [2] added in this subfamily Chelictinia and placed Gampsonyx in Falconidae (Leach, 1820). Friedmann [20] moved it back to Elaninae.

The modern constitution of this group was proposed by Jollie [21-23] based on the morphology of the bones, muscles, and plumage. He considered "elanins" as Elanus, Gampsonyx, and Chelictinia within the subfamily of Milvinae (Vigors, 1825), or as a separate subfamily which might be doubtfully enlarged with Ictinia (Vieillot, 1816), Harpagus (Vigors, 1824), and Macheiramphus [23]. Stresemann and Amadon in the second edition of the first volume of Peters's "Check-list of birds of the world" placed Elanus, Gampsonyx, and Chelictinia as the majority of diurnal raptors genera to the large Accipitrinae subfamily [24]. Wolters [25], on the other hand, proposed multiple subfamilies in the Accipitridae; among them, Elaninae with Elanus and Chelictinia and monotypic Gampsonychinae (Wolters, 1975). Because Wolters did not provide a diagnosis for this taxon and other new taxa, they must be considered as nomina nuda and are not valid according to the International Code of Zoological Nomenclature (Article 13). Amadon and Bull [26] added Macheiramphus to Elaninae again. Recently, the name of Elaninae as a subfamily of Accipitridae with three genera-Elanus, Gampsonyx, and Chelictinia-was used after an analysis of mitochondrial sequences by Lerner and Mindell [3], which is close to the first classification proposed by Blyth a century and a half ago.

Before the molecular era, Elaninae, like other kites, were considered by their morphology as an old and primitive group of the Accipitridae [4,23,27]. In the family tree of Accipitridae, the Elaninae are found as the most ancient branch, and their position is basal to other subfamilies, including different kite genera after trees based on mitochondrial $C y t b[28,29]$, combined mitochondrial and nuclear $C y t b+R A G-1$ [30], Cyt b+ND2+BF-I7 [3], and Cyt b+RAG-1+GAPDH+LDH+AK+c-myc+c-mos [31] sequences. Moreover, because of their distant position to the "main" Accipitridae, we proposed to treat this group as a separate family Elanidae [28,29], and even the suggestion of the order Elaniformes was raised [32]. Further research on raptor molecular phylogeny confirmed that Macheirhamphus as well as Elanoides, which were formerly placed in Elaninae, are distant from Elanus. However, Gampsonyx appears to be closer to Elanus [3,31,33].

The aim of this study is to analyze the molecular phylogeny of the Elanin kite group and its position in the order Accipitriformes (Vieillot, 1816), using nucleotide sequences of the mitochondrial cytochrome $b(C y t b)$ and cytochrome oxidase $1(\mathrm{COI})$ genes, and the nuclear recombination-activating gene 1 (RAG-1). Results are discussed in relation to their taxonomy, morphology, ecology, and geographic distribution.

\section{Materials and Methods}

\subsection{Laboratory Procedures}

Samples from 17 wild individuals of Elanus caeruleus, E. axillaris, E. leucurus, and Chelictinia riocourii deposited in the specimen collection of the Institute of Pharmacy and Molecular Biotechnology (IPMB) were investigated (Table 1, Figure 1), GenBank accession numbers MT800519-MT800541, MT897851-MT897865. The DNA was extracted from tissue, feather, and blood samples and isolated using standard proteinase K (Merck, Darmstadt) and a phenol/chloroform protocol [34]. The loci were amplified using specific primers (Table 2). 
Table 1. Samples of Elanin kites used in the phylogenetic analysis

\begin{tabular}{|c|c|c|c|c|c|}
\hline \multirow{2}{*}{ Taxon } & \multirow{2}{*}{ Origin } & \multirow{2}{*}{ Source } & \multicolumn{3}{|c|}{ IPMB Number/GenBank Accession Number/BOLD Process ID } \\
\hline & & & Cyt b & $\mathrm{COI}$ & $R A G-1$ \\
\hline Elanus caeruleus caeruleus & Egypt & This study & IPMB373/MT800519 & IPMB373/MT800534 & IPMB373/MT897851 \\
\hline Elanus caeruleus caeruleus & Morocco & This study & IPMB4251/MT800520 & IPMB4251/MT800535 & IPMB4251/MT897852 \\
\hline Elanus caeruleus caeruleus & South Africa, Cape Province & This study & IPMB9965/MT800521 & IPMB9965/MT800536 & IPMB9965/MT897853 \\
\hline Elanus caeruleus caeruleus & South Africa, Cape Province & This study & IPMB9966/MT800522 & IPMB9966/MT800537 & IPMB9966/MT897854 \\
\hline Elanus caeruleus caeruleus & South Africa, Cape Province & This study & IPMB9967/MT800523 & - & IPMB9967/MT897855 \\
\hline Elanus caeruleus caeruleus & Namibia, Okaukuejo & This study & IPMB20593/MT800524 & - & IPMB20593/MT897856 \\
\hline Elanus caeruleus caeruleus & Namibia, Windhoek & This study & IPMB47115/MT800525 & - & IPMB47115/MT897857 \\
\hline Elanus caeruleus caeruleus & Namibia, Windhoek & This study & IPMB47116/MT800526 & IPMB47116/MT800538 & IPMB47116/MT897858 \\
\hline Elanus caeruleus caeruleus & Namibia, Windhoek & This study & IPMB47117/MT800527 & - & IPMB47117/MT897859 \\
\hline Elanus caeruleus caeruleus & Namibia, Windhoek & This study & IPMB47118/MT800528 & - & IPMB47118/MT89786C \\
\hline Elanus caeruleus caeruleus & Namibia, Windhoek & This study & IPMB47119/MT800529 & - & - \\
\hline Elanus caeruleus caeruleus & Benin, Cotonou & This study & IPMB58999/MT800530 & - & IPMB58999/MT897861 \\
\hline Elanus caeruleus caeruleus & Benin, Bohicon & This study & IPMB75231/MT800531 & IPMB75231/MT800539 & IPMB75231/MT897862 \\
\hline Elanus caeruleus vociferus & Thailand & $\begin{array}{c}\text { Boonyaprakob and } \\
\text { Kasorndorkbua, unpubl. }\end{array}$ & - & MK932886 & 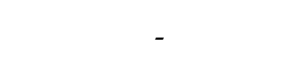 \\
\hline Elanus caeruleus ssp. & unknown & [33] & - & - & EF078724 \\
\hline Elanus leucurus leucurus & $\begin{array}{c}\text { Argentina, San Cayetano } \\
\text { (Corrientes) }\end{array}$ & [35] & - & FJ027543/KBARG184-07 & - \\
\hline Elanus leucurus majusculus & USA & {$[3]$} & AY987233 & - & - \\
\hline Elanus leucurus majusculus & Panama, Pacora & $\begin{array}{l}\text { Smithsonian Tropical Res. } \\
\text { Inst., unpubl. }\end{array}$ & - & BSENC001-06 & - \\
\hline Elanus leucurus majusculus & Panama, Pacora & $\begin{array}{l}\text { Smithsonian Tropical Res. } \\
\text { Inst., unpubl. }\end{array}$ & - & BSPAC008-14 & - \\
\hline Elanus leucurus majusculus & USA, Rodeo (California) & {$[36]$} & - & DQ432907/CDMVZ014-05 & - \\
\hline Elanus leucurus majusculus & USA, Berkeley & [36] & - & DQ432908/CDMVZ015-05 & - \\
\hline Elanus axillaris & Australia, Birriwa vicinity & This study & - & - & IPMB8050/MT897863 \\
\hline Elanus axillaris & Australia, Canberra & This study & - & - & IPMB29917/MT897864 \\
\hline Elanus axillaris & Australia, Canberra & This study & IPMB29920/MT800532 & IPMB29920/MT800540 & - \\
\hline Gampsonyx swainsonii swainsonii & $\begin{array}{c}\text { Argentina, San Cayetano } \\
\text { (Corrientes) }\end{array}$ & $\begin{array}{l}\text { Mus. Argent. Cienc. Nat. } \\
\text { Rivadavia, unpubl. }\end{array}$ & - & FJ027613/KBAR776-06 & - \\
\hline Gampsonyx swainsonii swainsonii & Brazil, Serra das Confusoes & {$[37]$} & - & JN801680/LGEMA021-07 & - \\
\hline Gampsonyx swainsonii swainsonii & Brazil, Tailândia & [37] & - & LGEMA404-08 & - \\
\hline Gampsonyx swainsonii leonae & $\begin{array}{l}\text { Guyana, Saddle Mountain } \\
\text { vicinity }\end{array}$ & [38] & - & JQ174910/USNMI208-11 & - \\
\hline
\end{tabular}


Table 1. Cont.

\begin{tabular}{|c|c|c|c|c|c|}
\hline \multirow{2}{*}{ Taxon } & \multirow{2}{*}{ Origin } & \multirow{2}{*}{ Source } & \multicolumn{3}{|c|}{ IPMB Number/GenBank Accession Number/BOLD Process ID } \\
\hline & & & Cyt b & COI & $R A G-1$ \\
\hline Gampsonyx swainsonii leonae & $\begin{array}{c}\text { Guyana, Saddle Mountain } \\
\text { vicinity }\end{array}$ & [38] & - & JQ174911/USNMK306-11 & - \\
\hline Gampsonyx swainsonii leonae & Panama, Pacora & $\begin{array}{l}\text { Smithsonian Tropical Res. } \\
\text { Inst., unpubl. }\end{array}$ & - & BSPBA002-07 & - \\
\hline Gampsonyx swainsonii leonae & Panama, Puerto Armuelles & $\begin{array}{l}\text { Smithsonian Tropical Res. } \\
\text { Inst., unpubl. }\end{array}$ & - & BSPBA005-07 & - \\
\hline Gampsonyx swainsonii leonae & $\begin{array}{c}\text { Colombia, Caño Agua Verde } \\
\text { (Arauca) vicinity }\end{array}$ & $\begin{array}{l}\text { Inst. Invest. Recurs. Biol. } \\
\text { von Humboldt, unpubl. }\end{array}$ & - & IAVHB082-13 & - \\
\hline Gampsonyx swainsonii leonae & unknown & {$[33]$} & - & - & EF078725 \\
\hline Chelictinia riocourii & Nigeria, Agbor & This study & IPMB47157/MT800533 & IPMB47157/MT800541 & IPMB47157/MT897865 \\
\hline
\end{tabular}

Table 2. Primers used in this study.

\begin{tabular}{|c|c|c|c|}
\hline Gene & Primer & Sequence $\left(5^{\prime}-3^{\prime}\right)$ & Reference \\
\hline \multirow{4}{*}{ Cyt $b$} & L14764 & F-TGRTACAAAAAAATAGGMCCMGAAGG & [39] \\
\hline & MT-c2 & F-TGAGGACAAATATCATTCTGAGG & {$[40,41]$} \\
\hline & Mt-Fr & R-CTAAGAAGGGTGGAGTCTTCAGTTTTTGGTTTACAAGAC & [39], modified \\
\hline & Mt-E & R-GCAAATAGGAAGTATCATTCTGG & [41] \\
\hline \multirow{2}{*}{$\mathrm{COI}$} & Passer F1 & F-CCAACCACAAAGACATCGGAACC & [42] \\
\hline & Passer R1 & R-GTAAACTTCTGGGTGACCAAAGAATC & [42] \\
\hline \multirow{2}{*}{$R A G-1$} & R17 & F-CCCTCCTGCTGGTATCCTTGCTT & [43] \\
\hline & $\mathrm{R} 51$ & R-GACCCTCTTTCTGCTATGAGGGGGC & [44] \\
\hline
\end{tabular}


PCR amplifications were carried out in $50 \mu \mathrm{L}$ reaction volumes containing PCR buffer, $100 \mu \mathrm{M}$ dNTPs, 0.2 units of Taq DNA polymerase (Bioron, Ludwigshafen), $200 \mathrm{ng}$ of DNA, and 5 pmol of primers. PCR conditions were set as follows for $\mathrm{Cyt} b / \mathrm{COI} / \mathrm{RAG}-1$, respectively: $95 / 95 / 94^{\circ} \mathrm{C}$ initialization for $5 \mathrm{~min}$; $95 / 95 / 94{ }^{\circ} \mathrm{C}$ denaturation for $45 \mathrm{~s}, 54 / 50 / 54{ }^{\circ} \mathrm{C}$ for annealing temperature for $1 \mathrm{~min}$, and $72{ }^{\circ} \mathrm{C}$ for extension for $1.5 / 2 / 2 \mathrm{~min}$, running in 38 cycles. A final elongation step was conducted at $72{ }^{\circ} \mathrm{C}$ for $10 \mathrm{~min}$.

The PCR product was purified by precipitation in $4 \mathrm{M} \mathrm{NH}_{4} \mathrm{Ac}$ and absolute ethanol (1:1:10), centrifuged at 13,000 rpm for a period of $30 \mathrm{~min}$, followed by centrifugation with $70 \%$ ethanol using the same settings and later dissolved in $25 \mu \mathrm{L}$ of sterile $\mathrm{H}_{2} \mathrm{O}$. For sequencing, $1 \mu \mathrm{L}$ of sequencing primer $(10 \mathrm{pmol} / \mu \mathrm{L})$ was combined with a $7 \mu \mathrm{L}$ mixture of PCR products/sterile water (where the concentration of PCR products varied from 1 to $7 \mu \mathrm{L}$ according to the brightness of the band obtained in $1.4 \%$ agarose gel).

Sanger sequencing was carried out on ABI 3730 automated capillary sequencer (Applied Biosystems, Carlsbad, CA, USA) with the ABI Prism Big Dye Terminator Cycle Sequencing Ready Reaction Kit 3.1 (executed by STARSEQ GmbH, Mainz, Germany).

\subsection{Phylogenetic Analysis}

Mitochondrial DNA sequences were controlled in order to exclude the possibility of stop codons, indicating that these sequences did not come from nuclear copies. Alignments were created in BioEdit 7.2.6 [45], nucleotide sequences were aligned using the MUSCLE algorithm [46].

We analyzed 1039 aligned base pairs (bp) of $C y t b, 604 \mathrm{bp}$ of COI, and $878 \mathrm{bp}$ of RAG-1 genes of Elaninae. Some sequences remained unsuccessful. A total of 17 sequences from GenBank and Barcode of Life Data System (BOLD) databases were added in the analysis, thus, we examined all taxa of Elaninae except E. scriptus (Table 1, Figure 1). Maximum Likelihood and Neighbor-Joining trees for each locus and average pairwise p-distances were calculated with MEGA 6.06 [47]. Relative branch support was evaluated with 1000 bootstrap replicates for the Maximum Likelihood and 10,000 for Neighbor-Joining trees.

For phylogenetic analysis, we added Bat Hawk Macheiramphus alcinus (Bonaparte, 1850), and Swallow-tailed Kite Elanoides forficatus (Linnaeus, 1758) sequences [3,33,36], formerly belonging to the same group with Elanus; one species per genera, for which we found sequences from all three genes, considered actually or in the past as a kite [2,3,7,48]: Ictinia, Milvus (Lacépède, 1799), Haliastur (Selby, 1840), Rostrhamus (Lesson, 1830), Pandion Savigny, 1809, sequences [3,33,35,37,49-52]; sequences from three genes of representatives from different subfamilies, one species for each, of Accipitridae [53-58], and other diurnal raptors as Secretarybird [59] and a falcon [60] from complete mitogenomes deposited in GenBank, nuclear IPMB (GenBank accession numbers MT897866-MT897875), and GenBank sequences as outgroup.

Bayesian concatenated mitochondrial and nuclear gene trees were calculated using BEAUti 1.8.0 [61]. For finding the best evolution model, jModelTest 2.1.10 was applied [62,63] with the Akaike information criterion [64], which showed a GTR $+\mathrm{I}+\Gamma$ model for $C y t b$ and COI complete datasets, $\operatorname{TrN}+\Gamma$ for the $R A G-1$ dataset, TPM1uf $+\Gamma$ for $C y t b$, and TIM2 $+\mathrm{I}+\Gamma$ for separate COI kite datasets. Because the three last (and many other) models are not available in the BEAST/BEAUti package, they were changed to the most similar by $\Delta$ of corrected AIC, and finally GTR+I [65,66], GTR $+\Gamma$, and GTR $+\mathrm{I}+\Gamma[65,67,68]$ were chosen for $R A G-1$, separate kites $C y t b$, and all other datasets, respectively. To set the rates of the clock model, we used the half-value of the $2.1 \%$ sequence divergence per million years for $C y t b$, which is accepted for birds [69], and $1.8 \%$ for COI [70], the estimated rate with lognormal prior distribution of the substitution rate for nuclear alignment. We chose the strict clock model, Yule speciation process [71,72], for the Markov chain Monte Carlo method to measure the length of the chain set with 10 million runs, sampling every 1000th run. Phylogenetic trees were performed in BEAST 1.8.0 [61], log files were checked for convergence of runs in Tracer 1.7.1 [73], and the trees with 
the best likelihood were summarized using TreeAnnotator 1.8.0 [61], and the first 10\% of trees were discarded as burn-in. Completed phylogenetic trees were arranged and visualized in FigTree 1.4.3.

\section{Results}

The numbers of parsimony-informative and variable uninformative sites for Elanin kites were 91 and $118 \mathrm{bp}$ of a total $1039 \mathrm{bp}$ for Cyt b, 114 and $31 \mathrm{bp}$ of $604 \mathrm{bp}$ for COI, and 5 and $16 \mathrm{bp}$ of $878 \mathrm{bp}$ for $R A G-1$ gene loci, respectively. Sequence divergences using pairwise distances are relatively high and consist up to $2.2 \%$ for COI between subspecies, 8.7-10.9\% for $C y t b$ and $8.8-9.6 \%$ for COI between species of the genus Elanus, and 11.4-13.0\% for $C y t b$ and $11.9-15.2 \%$ for COI between genera of the group (Table 3).

As can be seen from Figure 2, the families Sagittaridae (Finsch and Hartlaub, 1870), and Pandionidae (Sclater and Salvin, 1873), represent the basal branches of the order Accipitriformes. The group of all Elanin kites forms a separate clade basal to other Accipitridae, and its monophyly is confirmed with high support values for Bayesian Inference for mitochondrial gene sequences (Figure 2a) as well as for the nuclear $R A G-1$ gene (Figure $2 b$ ). As expected, other kites demonstrate polyphyly of this artificial group, forming clades together with different subfamily representatives, except Elanoides, which clusters with other non-Elaninae Accipitridae, with the genus being basal to the non-Elanin clade (Figure 2). Phylogenetic trees, which were constructed with ML and NJ, provide mostly identical topologies for separate mitochondrial and nuclear datasets (Figures S1-S3).

According to the molecular clock model used in Bayesian analysis, we can estimate the separation of Elaninae from other diurnal raptors at Early Miocene, 21.3 Mya (with 95\% interval of highest posterior density 24.9-17.6 Mya; Figure 3). The divergence within the group between Elanus and two other genera passed 16.7-15.3 Mya (95\% HPD = 20.1-12.7 Mya for both nodes), and the speciation inside Elanus occurred in Late Miocene 8.6-7.5 Mya (95\% HPD = 10.2-6.1 Mya for both nodes).

Chelictinia riocourii, which was never sequenced before, unequivocally, belongs to the Elaninae kite clade. The position of Gampsonyx swainsonii is more distant to the two other Elaninae genera. The separate position of Elanus axillaris in the genus as revealed by mitochondrial sequences is not confirmed by nuclear RAG-1 sequences. There are several different haplotypes inside Elanus caeruleus belonging to nominative subspecies supported by mitochondrial and nuclear data (Figure 2). 
Table 3. Pairwise p-distance values for taxa of Elaninae, Accipitridae, and other diurnal raptors used in the phylogenetic analysis, based on Cyt $b$ (below diagonal) and COI (above diagonal).

\begin{tabular}{|c|c|c|c|c|c|c|c|c|c|c|c|c|c|c|c|c|c|c|c|c|c|c|c|c|}
\hline $\begin{array}{l}\text { № } \\
\end{array}$ & Species & 1 & 2 & 3 & 4 & 5 & 6 & 7 & 8 & 9 & 10 & 11 & 12 & 13 & 14 & 15 & 16 & 17 & 18 & 19 & 20 & 21 & 22 & 23 \\
\hline 1 & $\begin{array}{c}\text { Elanus caeruleus } \\
\text { caeruleus }\end{array}$ & & - & 0.109 & - & 0.103 & 0.130 & - & - & 0.167 & 0.153 & 0.159 & 0.169 & 0.151 & 0.155 & 0.167 & 0.157 & 0.164 & 0.153 & 0.163 & 0.170 & 0.162 & 0.162 & 0.177 \\
\hline 2 & $\begin{array}{c}\text { Elanus caeruleus } \\
\text { vociferus }\end{array}$ & 0.022 & & - & - & - & - & - & - & - & - & - & - & - & - & - & - & - & - & & - & - & - & - \\
\hline 3 & Elanus axillaris & 0.090 & 0.088 & & - & 0.087 & 0.114 & - & - & 0.143 & 0.146 & 0.149 & 0.147 & 0.138 & 0.147 & 0.145 & 0.150 & 0.162 & 0.138 & 0.145 & 0.149 & 0.146 & 0.153 & 0.161 \\
\hline 4 & $\begin{array}{c}\text { Elanus leucurus } \\
\text { leucurus }\end{array}$ & 0.092 & 0.096 & 0.096 & & - & - & - & - & - & - & - & - & - & - & - & - & - & - & & - & - & - & - \\
\hline 5 & $\begin{array}{l}\text { Elanus leucurus } \\
\text { majusculus }\end{array}$ & 0.092 & 0.096 & 0.096 & 0.000 & & 0.127 & - & - & 0.162 & 0.158 & 0.154 & 0.154 & 0.150 & 0.150 & 0.164 & 0.156 & 0.160 & 0.143 & 0.160 & 0.164 & 0.149 & 0.161 & 0.176 \\
\hline 6 & Chelictinia riocourii & 0.133 & 0.131 & 0.123 & 0.141 & 0.141 & & - & - & 0.131 & 0.142 & 0.134 & 0.147 & 0.139 & 0.141 & 0.146 & 0.148 & 0.150 & 0.137 & 0.131 & 0.153 & 0.146 & 0.145 & 0.162 \\
\hline 7 & $\begin{array}{l}\text { Gampsonyx swainsonii } \\
\text { leonae }\end{array}$ & 0.137 & 0.136 & 0.151 & 0.119 & 0.119 & 0.128 & & - & - & - & - & - & - & - & - & - & - & - & - & - & - & - & - \\
\hline 8 & $\begin{array}{c}\text { Gampsonyx swainsonii } \\
\text { swainsonii }\end{array}$ & 0.138 & 0.137 & 0.152 & 0.121 & 0.121 & 0.129 & 0.000 & & - & - & - & - & - & - & - & - & - & - & - & - & - & - & - \\
\hline 9 & Elanoides forficatus & 0.163 & 0.164 & 0.159 & 0.164 & 0.164 & 0.149 & 0.153 & 0.154 & & 0.145 & 0.137 & 0.134 & 0.127 & 0.136 & 0.144 & 0.137 & 0.138 & 0.141 & 0.138 & 0.140 & 0.157 & 0.158 & 0.159 \\
\hline 10 & Ictinia plumbea & 0.156 & 0.161 & 0.157 & 0.157 & 0.157 & 0.137 & 0.141 & 0.141 & 0.142 & & 0.073 & 0.103 & 0.091 & 0.075 & 0.116 & 0.115 & 0.105 & 0.114 & 0.131 & 0.130 & 0.146 & 0.158 & 0.167 \\
\hline 11 & Rostrhamus sociabilis & 0.150 & 0.149 & 0.152 & 0.162 & 0.162 & 0.132 & 0.139 & 0.139 & 0.146 & 0.109 & & 0.103 & 0.095 & 0.080 & 0.113 & 0.123 & 0.106 & 0.118 & 0.130 & 0.133 & 0.142 & 0.161 & 0.174 \\
\hline 12 & Haliastur indus & 0.153 & 0.161 & 0.156 & 0.161 & 0.161 & 0.154 & 0.159 & 0.159 & 0.137 & 0.124 & 0.114 & & 0.075 & 0.100 & 0.124 & 0.121 & 0.113 & 0.117 & 0.132 & 0.144 & 0.157 & 0.168 & 0.174 \\
\hline 13 & Milvus migrans & 0.158 & 0.164 & 0.151 & 0.169 & 0.169 & 0.166 & 0.163 & 0.162 & 0.144 & 0.108 & 0.111 & 0.076 & & 0.093 & 0.111 & 0.116 & 0.108 & 0.114 & 0.130 & 0.121 & 0.150 & 0.154 & 0.158 \\
\hline 14 & Buteo buteo & 0.160 & 0.159 & 0.151 & 0.147 & 0.147 & 0.127 & 0.139 & 0.139 & 0.139 & 0.089 & 0.098 & 0.113 & 0.106 & & 0.113 & 0.119 & 0.109 & 0.121 & 0.130 & 0.133 & 0.146 & 0.160 & 0.176 \\
\hline 15 & Accipiter nisus & 0.138 & 0.151 & 0.144 & 0.167 & 0.167 & 0.152 & 0.154 & 0.156 & 0.154 & 0.123 & 0.121 & 0.127 & 0.123 & 0.136 & & 0.123 & 0.133 & 0.138 & 0.134 & 0.137 & 0.161 & 0.174 & 0.177 \\
\hline 16 & Circus cyaneus & 0.155 & 0.156 & 0.144 & 0.164 & 0.164 & 0.146 & 0.159 & 0.159 & 0.156 & 0.119 & 0.126 & 0.127 & 0.113 & 0.119 & 0.108 & & 0.131 & 0.134 & 0.138 & 0.135 & 0.162 & 0.167 & 0.172 \\
\hline 17 & Haliaeetus albicilla & 0.148 & 0.149 & 0.136 & 0.154 & 0.154 & 0.129 & 0.143 & 0.142 & 0.137 & 0.096 & 0.104 & 0.096 & 0.096 & 0.096 & 0.108 & 0.099 & & 0.131 & 0.149 & 0.141 & 0.149 & 0.171 & 0.177 \\
\hline 18 & Aquila chrysaetos & 0.143 & 0.151 & 0.137 & 0.166 & 0.166 & 0.129 & 0.151 & 0.151 & 0.144 & 0.116 & 0.134 & 0.123 & 0.127 & 0.126 & 0.109 & 0.123 & 0.109 & & 0.130 & 0.126 & 0.155 & 0.160 & 0.165 \\
\hline 19 & Spilornis cheela & 0.150 & 0.151 & 0.146 & 0.152 & 0.152 & 0.137 & 0.141 & 0.141 & 0.154 & 0.141 & 0.142 & 0.132 & 0.136 & 0.124 & 0.149 & 0.144 & 0.129 & 0.134 & & 0.132 & 0.149 & 0.156 & 0.166 \\
\hline 20 & Aegypius monachus & 0.148 & 0.156 & 0.154 & 0.162 & 0.162 & 0.149 & 0.151 & 0.151 & 0.154 & 0.129 & 0.134 & 0.119 & 0.126 & 0.126 & 0.141 & 0.118 & 0.123 & 0.137 & 0.132 & & 0.166 & 0.163 & 0.168 \\
\hline 21 & Pandion haliaetus & 0.145 & 0.144 & 0.154 & 0.157 & 0.157 & 0.121 & 0.148 & 0.149 & 0.139 & 0.139 & 0.156 & 0.147 & 0.149 & 0.141 & 0.142 & 0.149 & 0.132 & 0.136 & 0.142 & 0.161 & & 0.150 & 0.179 \\
\hline 22 & $\begin{array}{c}\text { Sagittarius } \\
\text { serpentarius }\end{array}$ & 0.166 & 0.171 & 0.164 & 0.169 & 0.169 & 0.146 & 0.156 & 0.156 & 0.161 & 0.166 & 0.157 & 0.146 & 0.164 & 0.156 & 0.171 & 0.175 & 0.159 & 0.159 & 0.169 & 0.152 & 0.151 & & 0.173 \\
\hline 23 & Falco peregrinus & 0.171 & 0.175 & 0.172 & 0.184 & 0.184 & 0.164 & 0.161 & 0.161 & 0.184 & 0.161 & 0.157 & 0.175 & 0.182 & 0.166 & 0.171 & 0.179 & 0.172 & 0.156 & 0.182 & 0.179 & 0.169 & 0.171 & \\
\hline
\end{tabular}


a

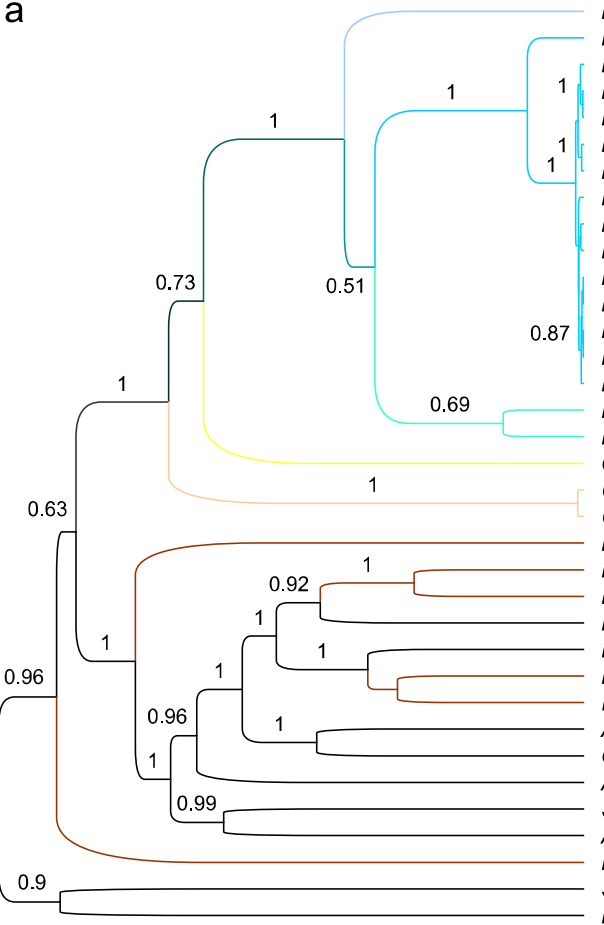

0.02
Elanus_axillaris_29920_Australia_Canberr

Elanus caeruleus 9965 South Africa

Elanus ceruleus 9966 South Africa

Elanus caeruleus 58999 Benin Cotonou

Elanus_caeruleus_75231_Benin_Bohicon

Elanus_caeruleus_9967_South_Africa

Elanus_caeruleus_20593_Namibia_Okaukuejo

tlanus_caeruleus_4251_Morocco

Elanus_caeruleus_373_Egypt

源

Elar

Elanus aeruleus 47116 Namibia Windhoek

Elanus caeruleus 47118 Namibia Windhoek

Elanus_leucurus_BOLD_5_USA_Panama_Argentina

Elanus_leucurus_AY987233_USA

Gampsonyx_Swainsonil_BOLD_6_Panama_Colombia_Brazil_Argentina

(a)

Haliastur indus_AY9887309.1_HM639875

Haliaeetus albicilla MK043028

Buteo_buteo_AF380305

Rostrhamus_sociabilis GQ264854 FJo28214

Ittinia_plumbea_GQ264822_JN801753

Accipiter_nisus_KM360148

Alrcus_cyaneus_KX925006

(Aquilachrysaetos_KF905228

Aegypius monachus KF682364

Pandion_haliaetus_DQ780884

Sagittarius_serpentarius_KF961184
Falco peregrinus_JQ282801

\section{b}

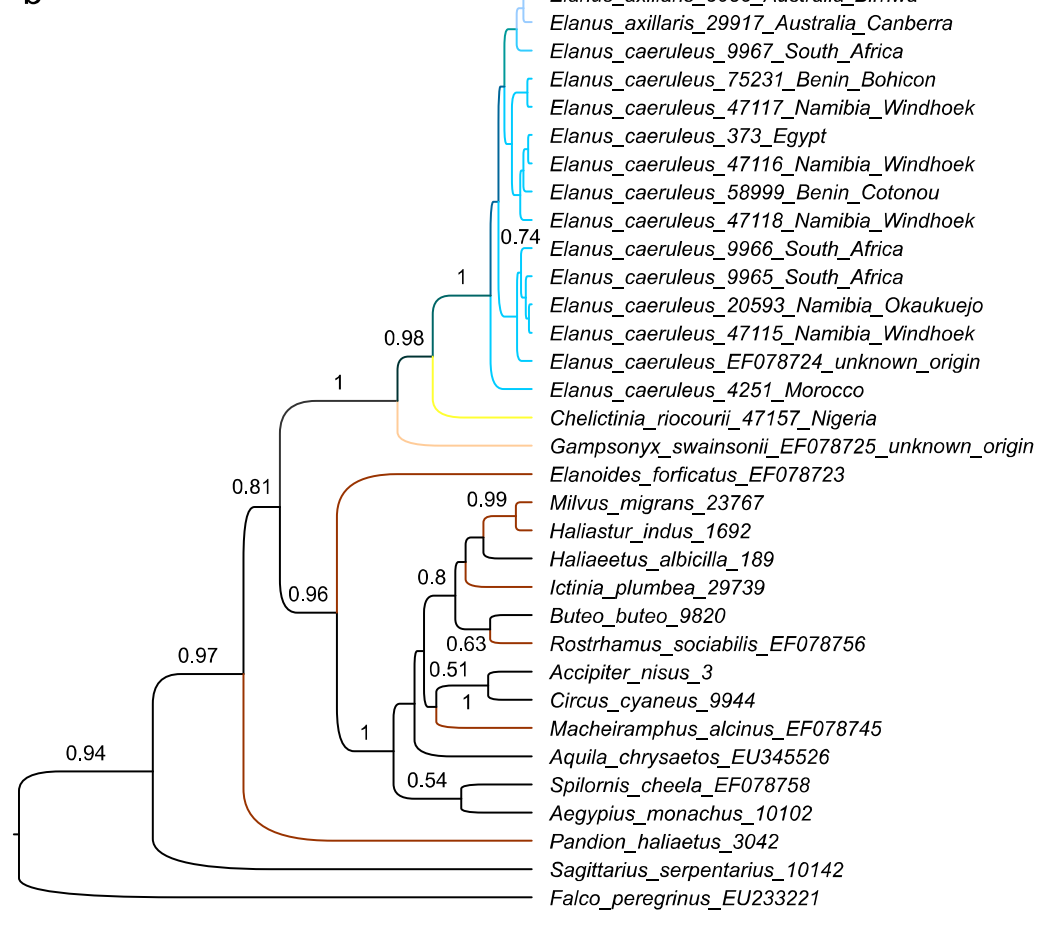

$\overline{0.002}$

Figure 2. Phylogenetic relationships between taxa of Elaninae (in colors), other kites (in brown), and diurnal raptors based on Bayesian Inference of concatenated mitochondrial dataset $C y t b+C O I(\mathbf{a})$ and nuclear dataset $R A G-1(\mathbf{b})$. Posterior probabilities $(>0.5)$ are indicated on the branches, last line represents number of substitutions per site. 


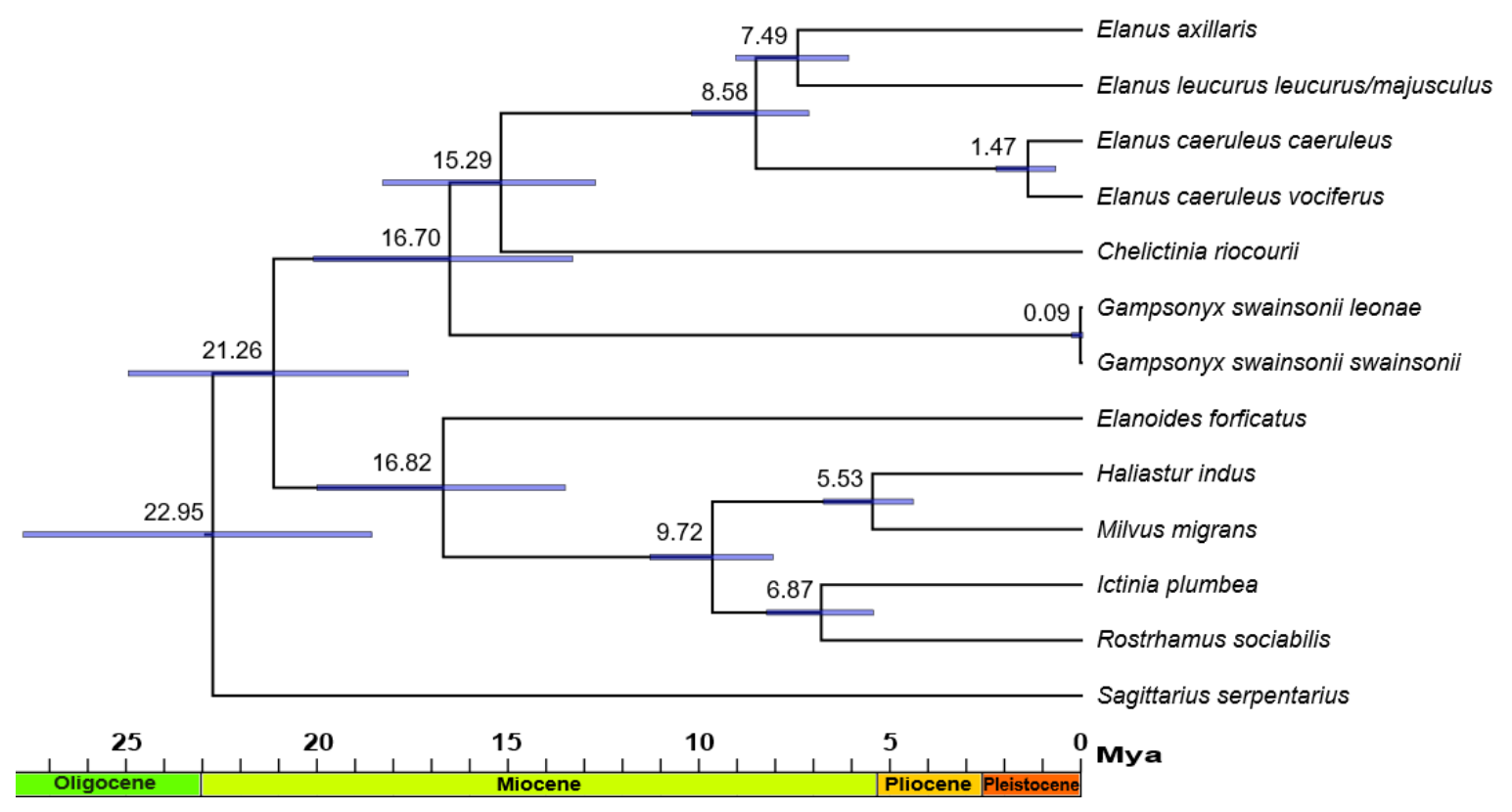

Figure 3. Phylogeny of elanins and other selected kites based on Bayesian Inference of the concatenated mitochondrial dataset. The secretarybird is an outgroup, node ages in million years ago are indicated on the branches. Node bars show the $95 \%$ highest posterior density of nodal age estimates.

\section{Discussion}

\subsection{Morphological Features of Elanin Kites}

Among evolutionary features, which distinguish elanins from other diurnal raptors, several morphological traits are found. Some of them are absent in other Accipitridae. Firstly, it has a primitive structure of the skull resembling birds of prey embryos [74]: the palate remains completely schizognathous [18]. This feature was later found in several Accipitridae genera [19,21], but are most strongly separated in Elaninae skull maxillopalatine processes [20,21]; the boundary of the foramen olfactorii is ossifying [74]; very low basicranial angle for Elanus and curved falcon-type form of the orbital process for Gampsonyx were also notified [22]. Features of limb bones: manus is longer than humerus, the inner spur of hypotarsus starts from the inner board of the shaft [19], distant positions of metatarsal scars (like Osprey) with a specific form of the middle trochlea, pillar-like medial process of calcaneal tuberosity, and "elanin subtype" of the tarsus in general as result of specialization for easy flexing of the toes. [22]. Other osteological traits are an absence of hypocleidium in furcula, specific form of coracoids-high position of coracoid foramen on procoracoid process and short sternocoracoid process, large depth of the keel and constitution of the sternum like Osprey, and the first cervical rib fused with the vertebra for Elanus [18,22,23].

Elanin kites equally have myological peculiarities. Among those related with limbs: the fully developed piriformis serves as origin for the parts of the flexor digitorum superficialis, outstanding flexor digitorum longus, wide tendons of internal flexor hallucis brevis, very weak peroneus longus, completely separated heads of the pars perforatus digiti III, as well as only medial and no lateral head of the pars perforatus digiti IV [23]. Other unique muscle types: ceratoglossus arise to the medial insertion of the massive transverses hyoideus like cathartids, Secretarybird, and in part Osprey; lack of pars mandibularis; muscles of innominate bones reach forward beneath the anterior plates of the ilia, and the caudilio-femoralis arising strongly forward by a tendon from the ventral point of the pygostyle. For Gampsonyx, the pars metapatagialis of latissimus dorsi is related with ribs not only three and four but equally five and six by aponeurosis like falcons [23]. 
Other unique morphological features of Elaninae are absent grooves on the claws [20]; almost complete absence of plumules on the crown for Gampsonyx [21], most distinct coloration parts among all Accipitriformes and absence of the median black throat stripe; weakly developed tympanic box in syrinx; and a simple gut: open duodenum, undeveloped ileum with absent supracecal loop [23]. The peculiarities which appear apparently independently during the evolution of elanins and other Accipitriformes should be added: lack of feathers in back patagium, also for the Hooded Vulture Necrosyrtes Gloger, 1841 [21]; perforated-type pelvis and reducing of zygomatic process like Macheirhamphus [22,23]; reducing of the insertion upon the third bronchial ring as for Buteo (Lacépède, 1799), hawks [23].

In recent study [75], Elanus, the well-investigated genus of this group is characterized unlike other diurnal birds of prey by owl-like features as a result of convergent evolution: zygodactylism (like Osprey), large frontally-placed eyes, vibrissae around the beck, velvet structure of upper parts of primary and secondary feathers as an adaptation for silent flight, and the producing of pellets with undigested bones as result of low stomach acidity [75]. The Elanus representatives are more or less nocturnal, the most night-active species is Elanus scriptus, which dispose an asymmetrical position of ear openings like several owls, which helps them to detect prey by sound [75]. Moreover, elanin eggs are intensively pigmented as falconid, and elements of their vocalization resemble the Barn Owl Tyto (Billberg, 1828)—screech, and falcons—chatter, maternal crock [32].

\subsection{Cytogenetics of Elanus caeruleus}

The study of the Black-winged Kite reveals its remarkable cytogenetic structure not observed in other Accipitridae [76]. Diurnal raptors have karyotype organized by medium-sized chromosomes with few numbers of small chromosomes, instead of macro- and dot-chromosome karyotypes of other birds. Elanus caeruleus show an even more specific organization with only one pair of microchromosomes. At the same time, nucleolus organizer regions of the Black-winged Kite are located on two chromosome pairs instead of one which is atypical for Accipitridae [77]. Finally, a comparison of its chromosome banding pattern with other raptor taxa demonstrates that high rearrangement and sex chromosomes of E. caeruleus are almost equal in size in contrast even to most other birds. All these particularities are considered as a result of chromosome evolution [76].

The specimens from India which should belong to E. c. vociferus (Latham, 1790) have been ascribed a diploid number of 66 chromosomes [78], while samples from Morocco and South Africa, which should be part of nominative subspecies that contain 68 [76] and 64 [79] chromosomes, respectively. However, the differences in the number of chromosomes between the latter two studies may be also erroneous in distinguishing and reporting microchromosomes [76]. This explanation seems more probable than the existence of populations in Southern Europe and Maghreb, which are significantly distinct in genetics and cytology from populations in the main range. Further research on the topic is necessary.

\subsection{Phylogenetics, Distribution, and Ecology of Elanins}

The molecular clock estimates of elanins based on our mitochondrial DNA data do not correspond to calculations on the appearance of different Accipitridae based on the calibration of three previously described raptor fossils, Osprey and two Buteo hawks [80], Snake Eagle and two vultures [81], both assuming a split for Elaninae of circa 34 Mya. The consistence between molecular and morphological data issued from fossils is usually not very high, and the retention index between phylogenetic trees [82] of two types of information for birds is 0.6-0.7 [83]. At the same time, our data are not far from previous estimations of the node Elanus/Gampsonyx with an age of 20.5 Mya (95\% HPD = 29.4-14.4 Mya) by Nagy and Tökölyi [80] and 16.7 Mya (95\% HPD = 20.1-13.3 Mya) by this study (Figure 3). We did not find any data on Elaninae fossils, and the fossilization is often not usual for tropical biomes, but its existence eventually could highlight the origin of this group. 
The position of Chelictinia riocourii has until recently been considered as provisional in absence of molecular data [7], and, traditionally, the Scissor-tailed Kite is placed in Elaninae [2]. Our study can thus confirm this assumption. The pairwise p-distances between genus Elanus and the two other genera, especially Gampsonyx, are comparable with the distances between representatives of different subfamilies in the order Accipitridae for $C y t b$ as well as for COI (Table 3) genes.

The phylogenetic position of subspecies of Elanus spp., including currently accepted and three formerly valid subspecies of E. caeruleus [84], cannot be determined with our dataset because of the lack of sufficient data. Several $C y t b$ and $R A G-1$ haplotypes of the African subspecies of the Black-winged Kite E. c. caeruleus (Desfontaines, 1789) were found across the entire continent (Figure 2a, Figures S1 and S2). This may be explained by the nomadic active movements as subadults, and adults across their wide range may exceed $1000 \mathrm{~km}$ [85], and the dispersal of nestlings (probably together with adult movements) even $3000 \mathrm{~km}$ [86]. The suggestion of Negro et al. [75] appears relevant, stating that the relatively nocturnal Elanus feeding on small rodents may occupy the niche which is mostly used by nomadic owls in the Northern Hemisphere. The difference between haplotypes of E. c. caeruleus, even for the more variable $C y t b$ gene, is low and the same haplotype appears in Egypt and South Africa. At the same time, two subspecies of E. leucurus show identical haplotypes for the accessible sequences of COI (Table 3). These subspecies are distinguished by small but significant size differences of wing, tail, and culmen [87,88], and their range is disrupted by the Amazonian basin [5], thus, the validity of these subspecies is not in doubt. However, we observed no distinction by the DNA-barcoding marker, but it apparently may be found with high-variable parts of the mitogenome as control region.

The Pearl Kite, the smallest Neotropical raptor, is morphologically and ecologically distinct from other elanins, being the smallest and most sedentary kite of this group (Table 4), and phylogenetically, this is the most distant taxon (Figures 2 and 3, Figures S2 and S3). These facts could suggest that the origin of Elaninae might be the Neotropic realm, and their migration trait probably appeared after a divergence of Gampsonyx from the common ancestor. The neotropical ancestor distribution for Elaninae is also estimated by Nagy and Tökölyi [77]. When the Pearl Kite was described, Vigors [89] notified its remarkable appearance to be close to falcons and hawks, but placed it together with hawks cause of the form of its bill and size of the wings. Later, this genus was placed to Falconidae by different authors [2,90-92] and back to Accipitridae [20,93-95] families. Three subspecies were described: nominative G. s. swainsonii (Vigors, 1825), G. s. leonae (Chubb, 1918), and G. s. magnus (Chubb, 1918). According to the geographic origin of the samples, our dataset should have molecular data for the two first subspecies. However, he difference in COI haplotypes between them is low or absent, and only birds from Guyana, which belong to the leonae race differ by one substitution (Table 2, Figures 2a and 3). The range of these subspecies adjoin each other, and swainsonii and leonae differ slightly only by their plumage colors: gray upper surface darker, straw-color instead of the orange-beige of forehead and sides; and the magnus race, which has no rufous on its flanks and is also separated geographically, differing by wing, and tail measurements $[5,96,97]$. We cannot reject that a clinal variation may exist for this species with a wide range, thus, inviting detailed morphological and genetic studies on Pearl Kite subspecies in the future. 
Table 4. Characteristics of elanin genera.

\begin{tabular}{|c|c|c|c|}
\hline & Elanus & Chelictinia & Gampsonyx \\
\hline Length $(\mathrm{cm})$ & $29-43$ & $33-38$ & $20-28$ \\
\hline Wing (cm) & $249-328$ & $225-254$ & $141-178$ \\
\hline Wingspan (cm) & $77-102$ & $68-76$ & $45-55$ \\
\hline Tail (cm) & $110-186$ & $170-216$ & $82-108$ \\
\hline Tarsus (mm) & $32-40$ & $28-33$ & $28-32$ \\
\hline Weight (g) & $160-427$ & $100-140$ & $94-140$ \\
\hline Plumage color & gray, black, and white & gray, black, and white & $\begin{array}{l}\text { black, white, rufous, } \\
\text { yellow }\end{array}$ \\
\hline Eyes color & red; orange-rufous (E. leucurus) & red & Chestnut, or red \\
\hline Range & $\begin{array}{l}\text { tropical and subtropical biomes } \\
\text { of the world }\end{array}$ & Subsaharan Africa & $\begin{array}{l}\text { Central and South } \\
\text { America }\end{array}$ \\
\hline Habitat & $\begin{array}{l}\text { open woodland, savanna, } \\
\text { grassland, farmland, urban } \\
\text { green areas, marsh, riverine } \\
\text { vegetation; cultivated steppe, } \\
\text { semi-desert, desert, rocks } \\
\text { (E. caeruleus); coastal dunes } \\
\text { (E. axillaris) }\end{array}$ & $\begin{array}{l}\text { semi-desert, savanna, } \\
\text { grassland }\end{array}$ & $\begin{array}{l}\text { open woodland, savanna, } \\
\text { scrub, urban green areas }\end{array}$ \\
\hline Altitude (m) & $0-3000(4200)$ & $0-500$ & $0-1000+$ \\
\hline Movements & $\begin{array}{l}\text { migratory or nomadic; also } \\
\text { sedentary (E. axillaris) }\end{array}$ & migratory, nomadic & $\begin{array}{l}\text { sedentary or locally } \\
\text { nomadic }\end{array}$ \\
\hline Feeding & $\begin{array}{l}\text { small mammals, also small birds, } \\
\text { reptiles and amphibians, large } \\
\text { insects; occasionally dead fish } \\
\text { (E. caeruleus) }\end{array}$ & $\begin{array}{l}\text { insects, arachnids, } \\
\text { lizards, also small snakes, } \\
\text { sometimes rodents }\end{array}$ & $\begin{array}{l}\text { lizards, large insects, } \\
\text { spiders, also snakes, } \\
\text { rodents }\end{array}$ \\
\hline Social behavior & $\begin{array}{l}\text { solitary or in pair; colonial } \\
\text { (E. scriptus) }\end{array}$ & colonial or in pair & solitary or in pair \\
\hline Nest place & $\begin{array}{l}\text { trees; occasionally bush } \\
\text { (E. caeruleus) or artificial } \\
\text { structures }\end{array}$ & trees or bush & trees \\
\hline Height of nest place (m) & $0.75-35$ & $2-8$ & $4-7$ \\
\hline Nest (across, cm) & $30-74$ & $30-40$ & 20 \\
\hline Number of eggs & $3-5(2-6)$ & 4 & $3-4(2-4)$ \\
\hline Egg measurements & $37-46 \times 29-36$ & $34-38 \times 27-31$ & $30 \times 24$ \\
\hline
\end{tabular}

Among the ecological features of elanins, parasites specific for these birds are worth mentioning separately. Clay [103] named the species group elani of Degeeriella (Neumann, 1906), a genus of Mallophaga (Nitzch, 1818), common for all genera of Elaninae, Elanoides, and Aviceda, that each of chewing lice species correspond to its own kite genus. It seems interesting to follow the cophylogeny of these lice and their hosts, like it was shown for other ectoparasites of different bird groups [104-107].

\subsection{Taxonomic Implications for Elanins and Other Accipitrids}

The South Asian subspecies of the Black-winged Kite Elanus caeruleus vociferus from India was described as full species [108]. The p-distance between African and the Thai E. caeruleus COI sequences (Table 2) is even higher than between several species of one genus in Accipitridae [109-113]. Their split occurred at $1.5 \pm 0.8 \mathrm{Mya}$ (Figure 3). We suppose that E.c. vociferus may be restored as species. This also may be confirmed by different karyotypes of this subspecies that we mentioned above. Nonetheless, this issue cannot be resolved without additional material gathered from different subspecies of E. caeruleus. Additionally, vociferus differs morphologically from other Black-winged Kites by well-defined black 
tips of underwing coverts [114]. It is curious that this race is not even recognized as a subspecies by Brown and Amadon [4] followed by Ferguson-Lees and Christie [5], merging it with caeruleus because of their close morphology, and Mees [115] leaves the validity of vociferus to be discussed. Currently, E. c. vociferus is present in all main bird checklists $[6,7,14]$.

At the same time, the position of Elanus axillaris sequences is contradictory. It is separate from large species E. caeruleus on the mitochondrial tree (Figure 2a), but both sequences of this species form clade with the Black-winged Kite (Figure 2b), though its support is very low (the posterior probabilities do not exceed 0.1). Apparently, the resolution of nuclear sequences $R A G-1$ is not sufficient to separate these species. Nonetheless, the tentative separation in mitochondrial but not in nuclear sequences may offer support to the suggestions of Debus [32] that the Australian E. axillaris is a recent species, split from E. caeruleus of the Old World. E. axillaris as well as the American E. leucurus were merged by some authors with the "main" species of the group as subspecies [84,114,116,117], which was not supported by other researchers $[4,20,24,118-120]$. Clark and Banks [88] found conclusive evidence for the validity of these three species based on morphometric differences between them. Currently, the Black-shouldered and White-tailed Kites are mentioned as full species in the checklists $[6,7,14]$. All three species are considered as allospecies, forming superspecies Elanus [caeruleus] $[24,88,118]$. The presence of E. axillaris in E. caeruleus clade may mean that the Black-shouldered Kite is not homogeneous, despite the fact that there are no morphological differences inside of the species. We recognize the current taxonomic status of the Elanus species with the remark that the final composition of this genus may be changed when data from more mitochondrial and nuclear markers or even whole genomes for each species and subspecies will be available.

Based on the synthesis of phylogenetic, cytogenetic, morphological, and ecological data, we recommend elevating Elaninae to Elanidae (Blyth, 1850) stat. nov. (LSID urn:lsid:zoobank.org: act:4E7580BA-7338-48F4-9100-B3A85F760B3C) conserving internal subfamily Elaninae and distinguishing inside a monotypic subfamily Gampsonychinae once proposed by Wolters as invalid taxon [25]. We provide the description of the new subfamily below.

The change of status of elanins invites to look at neighboring taxa: A large group of hawk-like diurnal birds of prey Accipitridae together with the families Elanidae and Pandionidae could be considered as suborder Accipitres (Linnaeus, 1758), proposed by Coues and Prentiss [121], whose composition was changed by several taxonomists [4,122-125] in new frames.

If we consider Cathartiformes as separate order [14], phylogenetically, the most distant taxon of the order Accipitriformes is a morphologically distinct primarily terrestrial large predator and sub-Saharan African endemic the Secretarybird Sagittarius serpentarius (Miller, 1779). The time of his separation from the main branch is relatively close to other Accipitriformes by our calculations (Figure 3) but more distant by the measures using fossil calibrations [80,81], and the Secretarybird branch is well-supported by different analyses (Figure 2), [3,33]. Thus, it confirm a monotypic suborder Serpentarii Seebohm, 1890. Other taxonomic ranks as infraorder Sagittarii (Seebohm, 1890) proposed by Cracraft [126] or Wetmore's superfamily Sagittariioidea (Finsch and Hartlaub, 1870) [127] seem less appropriate. Firstly, this taxon is phylogenetically (Figure 2) [3,31,33] and morphologically [21-23] more distant from other taxa of Accipitriformes and should not have the same taxonomic rank as those. Furthermore, Cracraft grouped the Secretarybird in suborder Accipitres together with infraorder Falconii, which consisted of all other diurnal raptors except New World vultures, and Wetmore considered all other diurnal birds of prey as second superfamily Falconoidea. Today, after the separation of former order Falconiformes in two [7] or even three [14] orders, these classifications are apparently outdated.

\section{Gampsonychinae Starikov \& Wink, subfam. nov.}

Type genus: Gampsonyx Vigors, 1825

Type species: Gampsonyx swainsonii Vigors, 1825

LSID: urn:lsid:zoobank.org:act:D25DE61A-7AE6-46BC-919A-44071B7AB9EA 
Diagnosis: The new subfamily is distinguished by combination of molecular phylogenetic, morphological and ecological data. Small falcon-like predators. Males and females have black upperparts, crown on the head, patch on breast side, bill, white underparts, chin and throat, yellow to orange forehead and cheeks. Plumules on the crown are practically absent. Orbital processes in the skull are rounded. Pars metapatagialis of latissimus dorsi muscle is related with ribs three to six. Mild sexual dimorphism, females are 10-20\% larger than males. Feeds on small lizards and large insects. Inhabits dry and arid regions, savannas, shrubs, snags, pastures, open woodlands, also edges of tropical evergreen forest. Non-migratory, nomads and juvenile dispersal. Distributed in Neotropics from El Salvador to North Argentina. Monotypic, one genus and species, three subspecies.

\section{Conclusions}

The examination of the molecular phylogeny of Elanin kites based on mitochondrial and nuclear markers confirms their position as sister taxa to other Accipitridae, and together with morphological, cytogenetic, and ecological data, lead to separating them in the family Elanidae. At the same time, the peculiarities of the Pearl Kite allow us to distinguish it as a monotypic subfamily Gampsonychinae, which forms Elanidae with a second subfamily Elaninae consisting of genera Elanus and Chelictinia. An accumulation of genetic data will permit us to clarify the phylogeny on a species-subspecies level of elanins in perspective. Phylogenetic relationships between Elanidae, Accipitridae, and Pandionidae from one side and the distant Secretarybird from the other allow us to classify them in two suborders of Accipitriformes.

Supplementary Materials: The following are available online at http://www.mdpi.com/1424-2818/12/9/327/s1. Figure S1: Cyt $b$ dataset trees constructed by Maximum Likelihood (a) and Neighbor-Joining (b) analyses. Figure S2: COI dataset trees constructed by Maximum Likelihood (a) and Neighbor-Joining (b) analyses. Figure S3: RAG-1 dataset trees constructed by Maximum Likelihood (a) and Neighbor-Joining (b) analyses. Bootstrap support values $(>50)$ are indicated on the trees branches, last lines represent number of substitutions per site.

Author Contributions: I.J.S. and M.W. developed the ideas and designed the study. I.J.S. performed the laboratory work, bioinformatic analysis, drew figures, and wrote the manuscript. M.W. provided material, laboratory supplies, and contributed important input for the manuscript. All authors have read and agreed to the published version of the manuscript.

Funding: The study was supported by Global Education Program grant to I.J.S.

Acknowledgments: We are grateful to our IPMB colleagues: Hedwig Sauer-Gürth for laboratory assistance and Erjia Wang for the support with Bayesian analysis; to Norbert Bahr and the two anonymous reviewers for their valuable comments; to the International Union for Conservation of Nature for the species range maps; and to all who provided elanin specimens for analysis: Australian National Parks and Wildlife Service, Walter Bednarek (Deutscher Falkenorden), Bertrand Bed'Hom (Muséum national d'Histoire naturelle), Walter Mangold (World of Birds Wildlife Sanctuary \& Monkey Park), Gerhard Nikolaus, Jerry Olsen (University of Canberra), Tim Osborne, and Steve Squire.

Conflicts of Interest: M.W. is the editor-in-chief of the Diversity journal. Otherwise, the authors declare that they have no conflict of interest.

\section{References}

1. Blyth, E. Conspectus of the ornithology of India, Burma, and the Malayan peninsula, inclusive of Sindh, Asám, Ceylon, and the Nicobar islands. J. Asiat. Soc. Bengal 1850, 19, 317-342.

2. Peters, J.L. Check-List of Birds of the World; Harward University Press: Cambridge, MA, USA, 1931 ; Volume 1.

3. Lerner, H.R.L.; Mindell, D.P. Phylogeny of eagles, Old World vultures, and other Accipitridae based on nuclear and mitochondrial DNA. Mol. Phylogenet. Evol. 2005, 37, 327-346. [CrossRef]

4. Brown, L.; Amadon, D. Eagles, Hawks, and Falcons of the World; McGraw-Hill Book Company: New York, NY, USA, 1968; Volume 1.

5. Ferguson-Lees, J.; Christie, D.A. Raptors of the World; Houghton Mifflin: Boston, MA, USA, 2001; ISBN 978-0-618-12762-7.

6. Dickinson, E.C.; Remsen, J.V., Jr. The Howard and Moore Complete Checklist of the Birds of the World, 4th ed.; Volume 1, Non-Passerines; Aves Press: Eastbourne, UK, 2013; ISBN 978-0-9568611-0-8. 
7. IOC World Bird List 10.1. Available online: http://www.iucnredlist.org/details/22695042/0 (accessed on 25 June 2020). [CrossRef]

8. Clements, J.F.; Schulenberg, T.S.; Iliff, M.J.; Billerman, S.M.; Fredericks, T.A.; Sullivan, B.L.; Wood, C.L. The eBird/Clements checklist of birds of the World: v2019. Available online: https://www.birds.cornell.edu/ clementschecklist/download/ (accessed on 3 May 2020).

9. Kemp, A.C.; Kirwan, G.M.; Marks, J.S.; Motis, A.; Garcia, E.F.J. Black-winged Kite (Elanus caeruleus). In Handbook of the birds of the World Alive; del Hoyo, J., Elliott, A., Sargatal, J., Christie, D.A., de Juana, E., Eds.; Available online: https://www.hbw.com/node/52966 (accessed on 3 May 2020).

10. BirdLife International. Elanus caeruleus. The IUCN Red List of Threatened Species 2019. Available online: https://www.iucnredlist.org/ (accessed on 18 June 2020). [CrossRef]

11. BirdLife International. Elanus leucurus. The IUCN Red List of Threatened Species 2016. Available online: https://www.iucnredlist.org/ (accessed on 18 June 2020). [CrossRef]

12. BirdLife International. Elanus axillaris. The IUCN Red List of Threatened Species 2016. Available online: https://www.iucnredlist.org/ (accessed on 18 June 2020). [CrossRef]

13. BirdLife International. Elanus scriptus. The IUCN Red List of Threatened Species 2016. Available online: https://www.iucnredlist.org/ (accessed on 18 June 2020). [CrossRef]

14. BirdLife International. Gampsonyx swainsonii. The IUCN Red List of Threatened Species 2016. Available online: https://www.iucnredlist.org/ (accessed on 18 June 2020). [CrossRef]

15. BirdLife International. Chelictinia riocourii. The IUCN Red List of Threatened Species 2016. Available online: https://www.iucnredlist.org/ (accessed on 18 June 2020). [CrossRef]

16. Ridgway, R. Catalogue of the ornithological collection of the Boston Society of Natural History. Part II. Falconidae. Proc. Boston Soc. Nat. Hist. 1873, 16, 43-72.

17. Ridgway, R. Studies of the American Falconidae. Bull. U. S. Geol. Geogr. Surv. Terr. 1876, 2, 91-182.

18. Shufeldt, R.W. Some comparative osteological notes on the North-American kites. IBIS 1891, 33, $228-232$. [CrossRef]

19. Pycraft, W.P. Contribution to the osteology of birds. Part V. Falconiformes. Proc. Zool. Soc. Lond. 1902, 1, 277-320.

20. Friedmann, H. The Birds of North and Middle America; Unites States National Museum; U.S. Government Printing Office: Washington, DC, USA, 1950; Volume XI.

21. Jollie, M. A contribution to the morphology and phylogeny of the Falconiformes (part II). Evol. Theory 1977, 2, 115-208.

22. Jollie, M. A contribution to the morphology and phylogeny of the Falconiformes (part III). Evol. Theory 1977, 2, 209-300.

23. Jollie, M. A contribution to the morphology and phylogeny of the Falconiformes (part IV). Evol. Theory 1977, 3, 1-141.

24. Stresemann, E.; Amadon, D. Order Falconiformes. In Check-list of Birds of the World; Museum of Comparative Zoology: Cambridge, MA, USA, 1979; Volume 1, pp. 271-425.

25. Wolters, H.E. Die Vogelarten der Erde: Eine Systematische Liste mit Verbreitungsangaben sowie Deutschen und Englischen Namen; Paul Parey: Hamburg, Deutschland; Berlin, Deutschland, 1982; ISBN 3-490-09118-3.

26. Amadon, D.; Bull, J. Hawks and owls of the world: An annotated list of species. Proc. West. Found. Vertebr. Zool. 1988, 3, 297-330.

27. Suschkin, P. Zur Morphologie des Vogelskelets: Vergleichende Osteologie der Normalen Tagraubvögel (Accipitres) und die Fragen der Classification; J.N. Kouchnéreff et C-ie: Moscou, Russie, 1905; Nouveaux mémoires de la Société impériale des naturalistes de Moscou, Tome XVI.

28. Wink, M. Advances in DNA studies of diurnal and nocturnal raptors. In Raptors at Risk, Proceedings of the 5th World Conference on Birds of Prey and Owls, Midrand, South Africa, 4-11 August 1998; Chancellor, R.D., Meyburg, B.-U., Eds.; WWGBP, Hancock House: London, UK, 2000; pp. 831-844.

29. Wink, M.; Sauer-Gürth, H. Phylogenetic relationships in diurnal raptors based on nucleotide sequences of Mitochondrial and Nuclear Marker Genes. In Raptors Worldwide, Proceedings of the 6 th World Conference on Birds of Prey and Owls, Budapest, Hungary, 18-23 May 2003; Chancellor, R.D., Meyburg, B.-U., Eds.; WWGBP: Berlin, Deutschland, 2004; pp. 483-498.

30. Starikov, I.J.; Sauer-Gürth, H.; Wink, M. Kites represent a polyphyletic group: Molecular phylogeny inferred from mitochondrial and nuclear DNA sequence. Vogelwarte 2018, 56, 331. 
31. Kocum, A. Phylogenie der Accipitriformes (Greifvögel) Anhand verschiedener nuklearer und mitochondrialer DNA-Sequenzen. Inauguraldissertation zur Erlangung des Akademischen Grades Doctor Rerum Naturalium (Dr. rer. nat.), Ernst-Moritz-Arndt-Universität Greifswald, Greifswald, Deutschland, 2006.

32. Debus, S. Relationships of the Elanus kites. Boobook 2004, 22, 8.

33. Griffiths, C.S.; Barrowclough, G.F.; Groth, J.G.; Mertz, L.A. Phylogeny, diversity, and classification of the Accipitridae based on DNA sequences of the RAG-1 exon. J. Avian Biol. 2007, 38, 587-602. [CrossRef]

34. Sambrook, J.; Russell, D.W. Molecular Cloning: A Laboratory Manual, 3rd ed.; Cold Spring Harbor Laboratory Press: Cold Spring Harbor, NY, USA, 2001; Volume 1, ISBN 0-87969-576-5.

35. Kerr, K.C.R.; Lijtmaer, D.A.; Barreira, A.S.; Hebert, P.D.N.; Tubaro, P.L. Probing evolutionary patterns in neotropical birds through DNA barcodes. PLoS ONE 2009, 4, e4379. [CrossRef]

36. Kerr, K.C.R.; Stoeckle, M.Y.; Dove, C.J.; Weigt, L.A.; Francis, C.M.; Hebert, P.D.N. Comprehensive DNA barcode coverage of North American birds. Mol. Ecol. Notes 2007, 7, 535-543. [CrossRef]

37. Tavares, E.S.; Gonçalves, P.; Miyaki, C.Y.; Baker, A.J. DNA barcode detects high genetic structure within Neotropical bird species. PLoS ONE 2011, 6, e28543. [CrossRef]

38. Schindel, D.; Stoeckle, M.; Milensky, C.; Trizna, M.; Schmidt, B.; Gebhard, C.; Graves, G. Project description: DNA barcodes of bird species in the National Museum of Natural History, Smithsonian Institution, USA. ZooKeys 2011, 152, 87-91. [CrossRef]

39. Sorenson, M.D.; Ast, J.C.; Dimcheff, D.E.; Yuri, T.; Mindell, D.P. Primers for a PCR-based approach to mitochondrial genome sequencing in birds and other vertebrates. Mol. Phylogenet. Evol. 1999, 12, 105-114. [CrossRef]

40. Wink, M.; Sauer-Gürth, H.; Heidrich, P.; Witt, H.-H.; Gwinner, E. A molecular phylogeny of stonechats and related turdids. In Stonechats. A Guide to the Genus Saxicola; Urquhart, E., Ed.; Helm: London, UK, 2002; pp. 22-29. ISBN 978-0-300-09970-6.

41. Barth, D.; Bernhard, D.; Fritzsch, G.; Fritz, U. The freshwater turtle genus Mauremys (Testudines, Geoemydidae)—A textbook example of an east-west disjunction or a taxonomic misconcept? Zool. Scr. 2004, 33, 213-221. [CrossRef]

42. Lohman, D.J.; Prawiradilaga, D.M.; Meier, R. Improved COI barcoding primers for Southeast Asian perching birds (Aves: Passeriformes). Mol. Ecol. Resour. 2009, 9, 37-40. [CrossRef]

43. Groth, J.G.; Barrowclough, G.F. Basal divergences in birds and the phylogenetic utility of the nuclear RAG-1 gene. Mol. Phylogenet. Evol. 1999, 12, 115-123. [CrossRef]

44. Irestedt, M.; Johansson, U.S.; Parsons, T.J.; Ericson, P.G.P. Phylogeny of major lineages of suboscines (Passeriformes) analysed by nuclear DNA sequence data. J. Avian Biol. 2001, 32, 15-25. [CrossRef]

45. Hall, T.A. BioEdit: A user-friendly biological sequence alignment editor and analysis program for Windows 95/98/NT. Nucleic Acids Symp. Ser. 1999, 41, 95-98.

46. Edgar, R.C. MUSCLE: Multiple sequence alignment with high accuracy and high throughput. Nucleic Acids Res. 2004, 32, 1792-1797. [CrossRef] [PubMed]

47. Tamura, K.; Stecher, G.; Peterson, D.; Filipski, A.; Kumar, S. MEGA6: Molecular Evolutionary Genetics Analysis Version 6.0. Mol. Biol. Evol. 2013, 30, 2725-2729. [CrossRef] [PubMed]

48. Jollie, M. A contribution to the morphology and phylogeny of the Falconiformes. Evol. Theory 1976, 1, 285-298.

49. Gibb, G.C.; Kardailsky, O.; Kimball, R.T.; Braun, E.L.; Penny, D. Mitochondrial genomes and avian phylogeny: Complex characters and resolvability without explosive radiations. Mol. Biol. Evol. 2007, 24, 269-280. [CrossRef]

50. do Amaral, F.R.; Sheldon, F.H.; Gamauf, A.; Haring, E.; Riesing, M.; Silveira, L.F.; Wajntal, A. Patterns and processes of diversification in a widespread and ecologically diverse avian group, the buteonine hawks (Aves, Accipitridae). Mol. Phylogenet. Evol. 2009, 53, 703-715. [CrossRef]

51. Ong, P.S.; Luczon, A.U.; Quilang, J.P.; Sumaya, A.M.T.; Ibañez, J.C.; Salvador, D.J.; Fontanilla, I.K.C. DNA barcodes of Philippine accipitrids. Mol. Ecol. Resour. 2011, 11, 245-254. [CrossRef]

52. Jeon, H.S.; Myeong, H.; Kang, S.-G.; Kim, J.A.; Lee, S.-H.; Lee, M.-Y.; An, J. The mitochondrial genome of Milvus migrans (Aves, Accipitriformes, Accipitridae), an endangered species from South Korea. Mitochondrial DNA Part B 2018, 3, 498-499. [CrossRef] 
53. Haring, E.; Kruckenhauser, L.; Gamauf, A.; Riesing, M.J.; Pinsker, W. The complete sequence of the mitochondrial genome of Buteo buteo (Aves, Accipitridae) indicates an early split in the phylogeny of raptors. Mol. Biol. Evol. 2001, 18, 1892-1904. [CrossRef] [PubMed]

54. Qin, X.-M.; Guan, Q.-X.; Shi, J.-P.; Hou, L.-X.; Qin, P.-S. Complete mitochondrial genome of the Spilornis cheela (Falconiformes, Accipitridae): Comparison of S. cheela and Spizaetus alboniger. Mitochondrial DNA 2013, 24, 255-256. [CrossRef] [PubMed]

55. Li, B.; Liu, G.; Zhou, L.; Gu, C. Complete mitochondrial genome of Cinereous vulture Aegypius monachus (Falconiformes: Accipitridae). Mitochondrial DNA 2015, 26, 910-911. [CrossRef] [PubMed]

56. Zhang, H.; Dou, H.; Yang, X.; Zhao, C.; Liu, G.; Zhang, J. The complete mitochondrial genome sequence of the Sparrowhawk (Accipiter nisus). Mitochondrial DNA 2014, 27, 1648-1649. [CrossRef] [PubMed]

57. Gao, X.; Sun, G.; Xia, T.; Zhao, C.; Wei, Q.; Sha, W.; Zhang, H. Complete mitochondrial genome sequence of the hen harrier (Circus cyaneus). Mitochondrial DNA Part B 2018, 3, 668-669. [CrossRef]

58. Kim, J.A.; Kang, S.-G.; Jeon, H.S.; Jeon, J.H.; Jang, J.-H.; Kim, S.; An, J. Complete mitogenomes of two Accipitridae, Haliaeetus albicilla, and Pernis ptilorhynchus. Mitochondrial DNA Part B 2019, 4, 391-392. [CrossRef]

59. Mahmood, M.T.; McLenachan, P.A.; Gibb, G.C.; Penny, D. Phylogenetic position of avian nocturnal and diurnal raptors. Genome Biol. Evol. 2014, 6, 326-332. [CrossRef]

60. Ryu, S.H.; Lee, J.H.; Hwang, U.W. Complete mitochondrial genome of the peregrine falcon Falco peregrinus (Aves, Falconiformes, Falconidae): Genetic differences between the two individuals. Mitochondrial DNA 2012, 23, 139-141. [CrossRef]

61. Drummond, A.J.; Suchard, M.A.; Xie, D.; Rambaut, A. Bayesian phylogenetics with BEAUti and the BEAST 1.7. Mol. Biol. Evol. 2012, 29, 1969-1973. [CrossRef]

62. Guindon, S.; Gascuel, O. A simple, fast and accurate method to estimate large phylogenies by maximum-likelihood. Syst. Biol. 2003, 52, 696-704. [CrossRef]

63. Darriba, D.; Taboada, G.L.; Doallo, R.; Posada, D. jModelTest 2: More models, new heuristics and parallel computing. Nat. Methods 2012, 9, 772. [CrossRef]

64. Akaike, H. A new look at the statistical model identification. IEEE Trans. Autom. Control 1974, 19, 716-723. [CrossRef]

65. Tavaré, S. Some probabilistic and statistical problems in the analysis of DNA sequences. In Some Mathematical Questions in Biology: DNA Sequence Analysis; Miura, R.M., Ed.; Lectures on Mathematics in the Life Sciences; American Mathematical Society: Providence, RI, USA, 1986.

66. Shoemaker, J.S.; Fitch, W.M. Evidence from nuclear sequences that invariable sites should be considered when sequence divergence is calculated. Mol. Biol. Evol. 1989, 6, 270-289. [CrossRef] [PubMed]

67. Yang, Z. Maximum likelihood phylogenetic estimation from DNA sequences with variable rates over sites: Approximate methods. J. Mol. Evol. 1994, 39, 306-314. [CrossRef]

68. Waddell, P.J.; Steel, M.A. General time-reversible distances with unequal rates across sites: Mixing gamma and inverse Gaussian distributions with invariant sites. Mol. Phylogenet. Evol. 1997, 8, 398-414. [CrossRef] [PubMed]

69. Weir, J.T.; Schluter, D. Calibrating the avian molecular clock. Mol. Ecol. 2008, 17, 2321-2328. [CrossRef] [PubMed]

70. Lavinia, P.D.; Kerr, K.C.R.; Tubaro, P.L.; Hebert, P.D.N.; Lijtmaer, D.A. Calibrating the molecular clock beyond cytochrome $b$ : Assessing the evolutionary rate of COI in birds. J. Avian Biol. 2016, 47, 84-91. [CrossRef]

71. Yule, G.U. A mathematical theory of evolution, based on the conclusions of Dr. Willis, J.C., Philos, F.R.S. Trans. R. Soc. Lond. B Biol. Sci. 1925, 213, 21-87.

72. Gernhard, T. The conditioned reconstructed process. J. Theor. Biol. 2008, 253, 769-778. [CrossRef]

73. Rambaut, A.; Drummond, A.J.; Xie, D.; Baele, G.; Suchard, M.A. Posterior summarization in Bayesian phylogenetics using Tracer 1.7. Syst. Biol. 2018, 67, 901-904. [CrossRef]

74. Suschkin, P. Beiträge zur Classification der Tagraubvögel mit Zugrundelegung der osteologischen Merkmale. Zool. Anz. 1899, 22, 500-518.

75. Negro, J.J.; Pertoldi, C.; Randi, E.; Ferrero, J.J.; López-Caballero, J.M.; Rivera, D.; Korpimäki, E. Convergent evolution of Elanus kites and the owls. J. Raptor Res. 2006, 40, 222-225. [CrossRef] 
76. Bed'Hom, B.; Coullin, P.; Guillier-Gencik, Z.; Moulin, S.; Bernheim, A.; Volobouev, V. Characterization of the atypical karyotype of the black-winged kite Elanus caeruleus (Falconiformes: Accipitridae) by means of classical and molecular cytogenetic techniques. Chromosome Res. 2003, 11, 335-343. [CrossRef]

77. De Boer, L.E.M.; Sinoo, R.P. A karyological study of Accipitridae (Aves: Falconiformes), with karyotypic descriptions of 16 species new to cytology. Genetica 1984, 65, 89-107. [CrossRef]

78. Ansari, H.A.; Kaul, D. Cytotaxonomic study in the order Falconiformes (Aves). Zool. Scr. 1986, 15, 351-356. [CrossRef]

79. Harris, T.; Walters, C. Chromosomal sexing of the Black Shouldered Kite (Elanus caeruleus) (Aves: Accipitridae). Genetica 1982, 60, 19-20. [CrossRef]

80. Nagy, J.; Tökölyi, J. Phylogeny, historical biogeography and the evolution of migration in accipitrid birds of prey (Aves: Accipitriformes). Ornis Hung. 2014, 22, 15-35. [CrossRef]

81. Mindell, D.P.; Fuchs, J.; Johnson, J.A. Phylogeny, taxonomy, and geographic diversity of diurnal raptors: Falconiformes, Accipitriformes, and Cathartiformes. In Birds of Prey. Biology and Conservation in the XXI Century; Sarasola, J.H., Grande, J.M., Negro, J.J., Eds.; Springer: Cham, Switzerland, 2018; pp. 3-32. ISBN 978-3-319-73744-7.

82. Farris, J.S. The retention index and rescaled consistency index. Cladistics 1989, 5, 417-419. [CrossRef]

83. Sansom, R.S.; Wills, M.A. Differences between hard and soft phylogenetic data. Proc. R. Soc. B Biol. Sci. 2017, 284, 1-7. [CrossRef]

84. Parkes, K.C. Specific relationships in the genus Elanus. Condor 1958, 60, 139-140.

85. Mendelsohn, J.M. Social-behaviour and dispersion of Blackshouldered Kite. Ostrich 1983, 54, 1-18. [CrossRef]

86. Oatley, T.B.; Oschadleus, H.D.; Navarro, R.A.; Underhill, T.G. Review of Ring Recoveries of Birds of Prey in Southern Africa: 1948-1998; Endangered Wildlife Trust: Johannesburg, South Africa, 1998; ISBN 978-0-620-22971-5.

87. Bangs, O.; Penard, T.E. Two new American hawks. Proc. N. Engl. Zoöl. Club 1920, 7, 45-47.

88. Clark, W.S.; Banks, R.C. The taxonomic status of the White-tailed Kite. Wilson Bull. 1992, 104, 571-579.

89. Vigors, N.A., Jr. Sketches in ornithology; or observations on the leading affinities of some of the more extensive groups of birds. Zool. J. 1825, 2, 37-70.

90. Pinto, O.M.d.O. Catalogo das aves do Brasil e lista dos exemplares que as representam no Museu Paulista; Museu Paulista: São Paulo, Brasil, 1938.

91. Hellmayr, C.E.; Conover, B. Catalogue of Birds of the Americas and the Adjacent Islands in Field Museum of Natural History and Including all Species and Subspecies Known to Occur in North America, Mexico, Central America, South America, the West Indies, and Islands of the Caribbean Sea, the Galapagos Archipelago, and other Islands which May Be Included on Account of Their Faunal Affinities; Field Museum Press: Chicago, IL, USA, 1949; Volume 13.

92. Meyer de Schauensee, R. The Birds of Colombia and Adjacent Areas of South and Central America; Livingston Publishing Company: Narberth, UK, 1964. Available online: http://globalraptors.org/grin/SpeciesResults. asp? specID=8035 (accessed on 18 June 2020).

93. Stresemann, V. The wing molt and systematic position of the genus Gampsonyx. Auk 1959, 76, 360-361. [CrossRef]

94. Brodkorb, P. The skeleton and systematic position of Gampsonyx. Auk 1960, 77, 88-89. [CrossRef]

95. Meyer de Schauensee, R. A Guide to the Birds of South America; Oliver \& Boyd: Edinburgh, UK, 1971; ISBN 978-0-05-002398-3.

96. Chubb, C. Descriptions of new forms from South and Central American birds-Gampsonyx swainsonii magnus, G. s. leonæ, Falco rufogularis petoensis, F. r. pax. Bull. Br. Ornithol. Club 1918, 39, 21-23.

97. Bierregaard, R.O., Jr.; Kirwan, G.M. Pearl Kite (Gampsonyx swainsonii). In Handbook of the Birds of the World Alive; del Hoyo, J., Elliott, A., Sargatal, J., Christie, D.A., de Juana, E., Eds.; Cornell Lab of Ornithology: Ithaca, NY, USA, 2020. Available online: https://www.hbw.com/node/52965 (accessed on 3 May 2020).

98. Clark, W.S.; Davies, R. African Raptors; Helm Identification Guides; Helm: London, UK, 2018; ISBN 978-0-7136-6538-3.

99. Bierregaard, R.O., Jr.; Marks, J.S.; Boesman, P.; Kirwan, G.M. White-Tailed Kite (Elanus leucurus). In Handbook of the Birds of the World Alive; del Hoyo, J., Elliott, A., Sargatal, J., Christie, D.A., de Juana, E., Eds.; Cornell Lab of Ornithology: Ithaca, NY, USA, 2020. Available online: https://www.hbw.com/node/52968 (accessed on 3 May 2020). 
100. Debus, S.; Kirwan, G.M.; Marks, J.S. Black-Shouldered Kite (Elanus axillaris). In Handbook of the Birds of the World Alive; del Hoyo, J., Elliott, A., Sargatal, J., Christie, D.A., de Juana, E., Eds.; Cornell Lab of Ornithology: Ithaca, NY, USA, 2020. Available online: https://www.hbw.com/node/52967 (accessed on 3 May 2020).

101. Debus, S.; Kirwan, G.M.; Christie, D.A.; Marks, J.S. Letter-Winged Kite (Elanus scriptus). In Handbook of the Birds of the World Alive; del Hoyo, J., Elliott, A., Sargatal, J., Christie, D.A., de Juana, E., Eds.; Cornell Lab of Ornithology: Ithaca, NY, USA, 2020. Available online: https://www.hbw.com/node/52969 (accessed on 3 May 2020).

102. Kemp, A.C.; Kirwan, G.M.; Marks, J.S. Scissor-Tailed Kite (Chelictinia riocourii). In Handbook of the Birds of the World Alive; del Hoyo, J., Elliott, A., Sargatal, J., Christie, D.A., de Juana, E., Eds.; Cornell Lab of Ornithology: Ithaca, NY, USA, 2020. Available online: https://www.hbw.com/node/52970 (accessed on 3 May 2020).

103. Clay, T. Revisions of the Mallophaga genera. Degeeriella from the Falconiformes. Bull. Br. Mus. Nat. Hist. Entomol. 1958, 7, 121-207.

104. Page, R.D.M.; Lee, P.L.M.; Becher, S.A.; Griffiths, R.; Clayton, D.H. A different tempo of mitochondrial DNA evolution in birds and their parasitic lice. Mol. Phylogenet. Evol. 1998, 9, 276-293. [CrossRef]

105. Banks, J.C.; Palma, R.L.; Paterson, A.M. Cophylogenetic relationships between penguins and their chewing lice. J. Evol. Biol. 2006, 19, 156-166. [CrossRef]

106. Hughes, J.; Kennedy, M.; Johnson, K.P.; Palma, R.L.; Page, R.D.M. Multiple cophylogenetic analyses reveal frequent cospeciation between pelecaniform birds and Pectinopygus Lice. Syst. Biol. 2007, 56, 232-251. [CrossRef] [PubMed]

107. Štefka, J.; Hoeck, P.E.; Keller, L.F.; Smith, V.S. A hitchhikers guide to the Galápagos: Co-phylogeography of Galápagos mockingbirds and their parasites. BMC Evol. Biol. 2011, 11, 1-18. [CrossRef]

108. Latham, J. Index Ornithologicus, Sive, Systema Ornithologiæ; Complectens Avium Divisionem in Classes, Ordines, Genera, Species, Ipsarumque Varietates: Adjectis Synonymis, Locis, Descriptionibus, Ec.; Leigh \& Sotheby: London, UK, 1790; Volume II.

109. Cai, Y.; Yue, B.; Jiang, W.; Xie, S.; Li, J.; Zhou, M. DNA barcoding on subsets of three families in Aves. Mitochondrial DNA 2010, 21, 132-137. [CrossRef] [PubMed]

110. Dolinay, M. Genetická struktura populací dvou druhů sympatricky se vyskytujících luňáků (Milvus spp.); Diplomová práce; Masarykova univerzita: Brno, Czech Republic, 2015.

111. Etherington, G.J.; Mobley, J.A. Molecular phylogeny, morphology and life-history comparisons within Circus cyaneus reveal the presence of two distinct evolutionary lineages. Avian Res. 2016, 7, 1-12. [CrossRef]

112. Retnaningtyas, R.W.; Hermadhiyanti, W.; Listyorini, D. The phylogenetic study of the White-Bellied Sea Eagle [Haliaeetus leucogaster (Gmelin, 1788)] based on DNA barcoding cytochrome-c oxidase subunit I (COI). In Proceedings of the ICBS Conference, Yogyakarta, Indonesia, 18-19 September 2015; KnE Life Sciences: Dubai, UAE, 2017; pp. 208-212.

113. Zein, M.S.A. Barkoding DNA burung Elang (Famili Accipitridae) di Indonesia. Ber. Biol. 2018, 17, $165-173$. [CrossRef]

114. Husain, K.Z. Notes on the taxonomy and zoogeography of the genus Elanus. Condor 1959, 61, $153-154$.

115. Mees, G.F. Birds from the lowlands of southern New Guinea (Merauke and Koembe). Zool. Verh. 1982, 191, $1-188$.

116. Rensch, B. Die Vogelwelt von Lombok, Sumbawa und Flores. Mitt. Zool. Mus. Berl. 1931, 17, 451-637.

117. Mees, G.F. On some birds from southern Mexico. Zool. Meded. 1970, 44, 237-245.

118. Mayr, E.; Short, L.L. Species Taxa of North American Birds. A Contribution to Comparative Systematics; Nuttall Ornithological Club: Cambridge, MA, USA, 1970.

119. Handbuch der Vögel Mitteleuropas; Glutz von Blotzheim, U.N.; Bauer, K.M.; Bezzel, E. (Eds.) Academische Verlagsgesellschaft: Frankfurt am Main, Deutschland, 1971; Volume 4.

120. Sibley, C.G.; Monroe, B.L. Distribution and Taxonomy of Birds of the World; Yale University Press: New Haven, London, UK, 1990; ISBN 978-0-300-04969-5.

121. Coues, E.; Prentiss, D.W. Avifauna Columbiana: Being a List of Birds Ascertained to Inhabit the District of Columbia, with the Times of Arrival and Departure of Such as Are Non-Residents, and Brief Notices of Habits, etc., 2nd ed.; U.S. Government Printing Office: Washington, DC, USA, 1883.

122. Seebohm, H. Classification of Birds; An Attempt to Diagnose the Subclasses, Orders, Suborders, and Some of the Families of Existing Birds; R.H. Porter: London, UK, 1890. 
123. Sharpe, R.B. A Review of Recent Attempts to Classify Birds; An Address Delivered before the Second International Ornithological Congress on the 18th of May, 1891; International Ornithological Congress: Budapest, Austria-Hungary, 1891.

124. Gadow, H. Dr. H.G. Bronn's Klassen und Ordnungen des Thier-Reichs, Wissenschaftlich Dargestellt in Wort und Bild; C. F. Winter'sche Verlagshandlung: Leipzig, Sachsen, 1893; Volume 6, Abteilung 4, II.

125. A Dictionary of Birds; Campbell, B.; Lack, E. (Eds.) T \& AD Poyser Ltd.: Calton, UK, 2010.

126. Cracraft, J. Toward a phylogenetic classification of the recent birds of the World (class Aves). Auk 1981, 98, 681-714.

127. Wetmore, A. A systematic classification for the birds of the World. Smithson. Misc. Collect. 1940, 99, 1-11. [CrossRef]

(C) 2020 by the authors. Licensee MDPI, Basel, Switzerland. This article is an open access article distributed under the terms and conditions of the Creative Commons Attribution (CC BY) license (http://creativecommons.org/licenses/by/4.0/). 